Reprod. Nutr. Dévelop., 1988, 28 (2 B), 487-497.

\title{
Involvement of melatonin in the seasonal changes of the gonadal function and prolactin secretion in female goats
}

\author{
K.-I. MAEDA, Y. MORI $\left({ }^{*}\right)$, Y. KANO $\left(^{* *}\right)$
}

Laboratory of Reproductive Physiology, School of Agriculture, Nagoya University, Nagoya, Japan.

(*) Laboratory of Veterinary Reproduction, Faculty of Agriculture, Tokyo University of Agriculture and Technology, Fuchu, Tokyo, Japan. ${ }^{* *}$ ) Laboratory of Animal Physiology, Faculty of Agriculture, Meiji University, Kawasaki, Japan.

Summary. Ovarian cyclicity in the goat continues under short days (8L : 16D), while it ceases for 150-200 days under long days (16L: 8D). During the anovulatory period under long days, prolactin secretion is enhanced. Experiments were conducted to investigate the role of the pineal gland in the photoperiodic control of the gonadal function and prolactin secretion in the goat.

Firstly, the effects of the abolition of the diurnal change in melatonin secretion on the photoperiodic responses of the gonadal axis and prolactin secretion were examined. Female Saanen goats, reared under short days $\left(8 \mathrm{~L}: 16 \mathrm{D}, 22 \pm 2{ }^{\circ} \mathrm{C}\right)$ for 5 months, were bilaterally superior cervical ganglionectomized (SCGX) to denervate their pineal gland. One month after surgery, both SCGX and intact control goats were divided into two groups. Animals in group 1 were maintained under short days and those in group 2 were transferred to long days $(16 \mathrm{~L}: 8 \mathrm{D})$. In group 1 , both SCGX and intact goats ovulated periodically and basal plasma levels of prolactin were maintained throughout the day. In intact controls, exposure to long days blocked ovulation and increased prolactin secretion for the first 150-200 days of exposure. The animals became photorefractory after this time; ovulation recurred and prolactin secretion was suppressed. The continuous melatonin secretion appeared simultaneously with the photorefractoriness. Superior cervical ganglionectomy abolished or weakened the suppression of gonadal axis and eliminated the increase in prolactin secretion induced by the exposure to long days in intact animals.

Secondly, the effect of melatonin replacement by timed melatonin infusion on prolactin secretion was examined in SCGX goats to establish that the effect of SCGX could be ascribed to the abolition of the diurnal change in melatonin. Ovariectomized SCGX Shiba goats $(\mathbf{n}=5)$ were infused with melatonin $(20 \mu \mathrm{g} / \mathrm{h}$, s.c.) daily for $8 \mathrm{~h}$ (the long-daytype infusion) and for $16 \mathrm{~h}$ (the short-day-type infusion) to mimic the nocturnal profiles of plasma melatonin under long days and short days, respectively. The long-day-type melatonin infusion for 9 days accelerated prolactin secretion, inducing a nocturnal rise in plasma prolactin ; this was comparable to that observed in intact controls under long days. On the other hand, by the short-day-type infusion, the plasma prolactin concentrations were maintained at a low level throughout the day as were observed in intact goats under short days. The prevailing photoperiod appeared to have no distinct effect on these prolactin responses to exogenous melatonin, which were indistinguishable under long and short days.

These results suggest that the information about light-dark cycles is converted by the pineal gland into the endocrine signal as a daily pattern of melatonin secretion, which eventually regulates reproductive endocrine events in the goat. 


\section{Introduction.}

The seasonal changes in gonadal activity and prolactin secretion are controlled by the photoperiod in female goats (Mori et al., 1984, 1985). Under short days, the gonadal axis is activated and prolactin secretion is maintained at a low level for more than a year. Exposure to long days suppresses the gonadal axis and increases prolactin secretion. These effects of long days continue, however, only for 150-200 days after exposure to long days; ovulation recurs and prolactin secretion decreases after this time in spite of continuous exposure to long days. This limited duration of the action of long days is also observed in the photoperiodic modification of negative and positive feedback effects of oestradiol on the luteinizing hormone secretion (Mori et al., 1987). The length of the period during which long days suppress the gonadal axis and stimulate prolactin secretion is almost equal to that of seasonal anoestrus in female goats (Mori et al., 1985 ; Yoshioka, 1961). These facts suggest that the onset of the breeding season in goats might be ascribed to the photorefractoriness of the animal to long days.

The involvement of the pineal gland and melatonin in the mechanism of seasonal breeding has been suggested in both long-day and short-day animals (Reiter, 1978 ; Herbert, 1981 ; Lincoln and Short, 1980 ; Karsch et al., 1984). As other mammalian species investigated so far (Bittman et al., 1983 ; Roberts et al., 1985), we have observed the diurnal changes in melatonin secretion in goats, which are synchronized with light-dark cycles (Maeda et al., 1984). The following experiments were conducted to determine the role of the pineal gland in the mechanism regulating the seasonal change in gonadal activity and the prolactin secretion.

\section{The effect of superior cervical ganglionectomy on the photoperiodic response of gonadal axis and prolactin secretion.}

Female Saanen goats reared under short days $\left(8 \mathrm{~L}: 16 \mathrm{D}, 22 \pm 2{ }^{\circ} \mathrm{C}\right.$ ) for 5 months, were bilaterally superior cervical ganglionectomized (SCGX). After a month of the recovery period, one group of goats (group 1) was maintained under short days and the others (group 2) were transferred to long days (16L : 8D). The ovarian activity and melatonin and prolactin secretion were monitored for 250 days after the surgery.

Figure 1 shows the changes in the diurnal pattern of plasma melatonin concentrations. In intact controls, plasma melatonin concentrations showed a marked rise during the dark period, and changes in photoperiod altered the duration of the rise in plasma melatonin concentrations, as were reported in many other mammalian species (Bittman et al., 1983 ; Roberts et al., 1985). Superior cervical ganglionectomy abolished this rise. Prolonged exposure to long days for about 150 days induced the " continuous " secretion of melatonin which was not synchronized with light-dark cycle. On days 146 and 223, the melatonin level 
throughout the day increased in both intact and SCGX goats of group 2, but not in group 1. This indicates that prolonged exposure of animals to long days for about 150 days induced the " continuous " secretion of melatonin which was not synchronized with the light-dark cycle and this secretion could not be controlled by the sympathetic nervous system through the superior cervical ganglion.

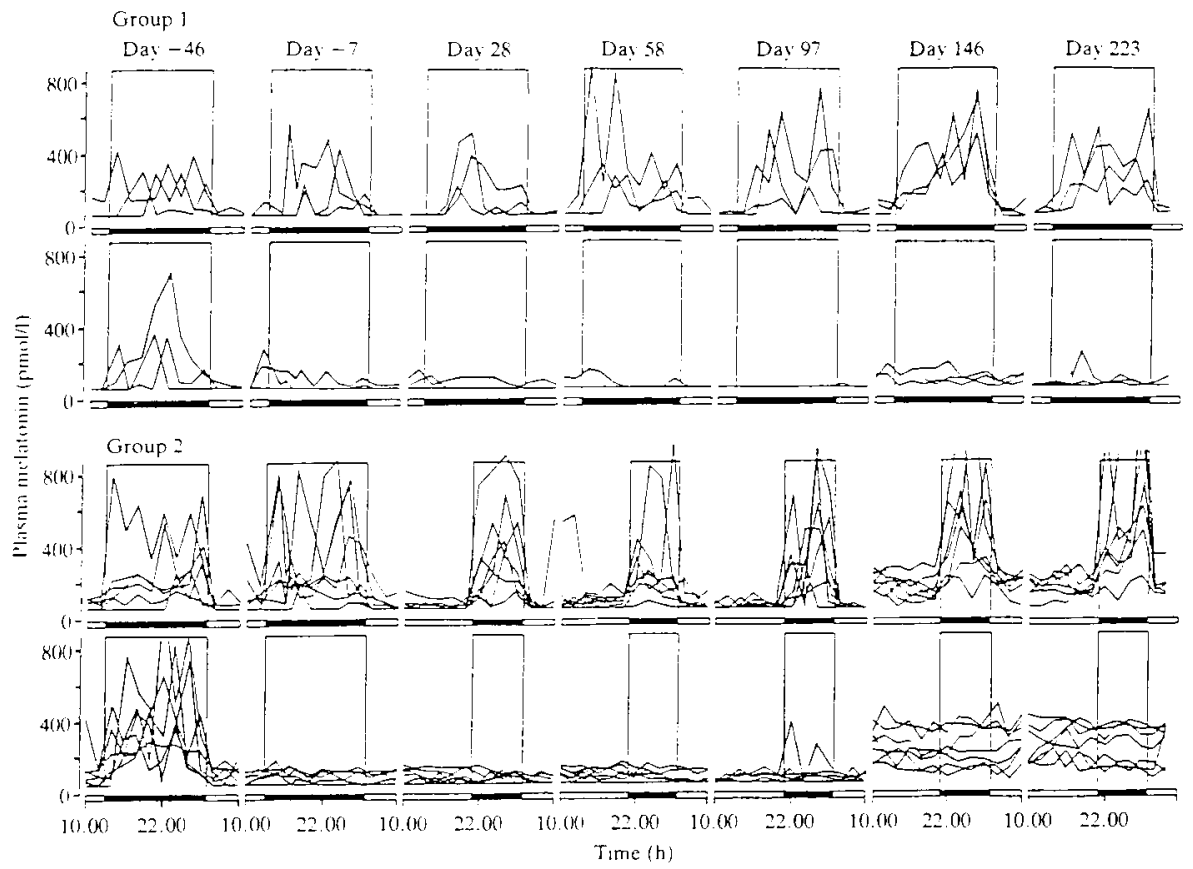

FIG. 1. - Patterns of the diurnal change in plasma melatonin levels in female goats in group 1 (maintained under short days) and group 2 (moved from short days to long days at day 0 ). In each group, intact (upper panels) and superior cervical ganglionectomized (SCGX ; lower panels) goats are shown. Individual values are shown for each group (group 1 ; three intact and three SCGX goats, group 2 ; seven intact and seven SCGX goats). Superior cervical ganglionectomy was performed between days - 37 and - 33. The solid horizontal bars indicate periods of darkness (Maeda et al., 1986).

The day of ovulations estimated by the fluctuation of plasma progesterone concentrations is shown in Figure 2. In group 1, both SCGX and intact goats cyclically ovulated for more than 200 days. In intact goats of group 2, ovulations were blocked immediately after the exposure to long days and ovulations recurred 150-200 days after the onset of the exposure to long days as we observed previously. In SCGX goats of group 2, this suppressive effect of long days on ovulatory cyclicity was weakened or ceased.

Figure 3 summarizes the long-term change in plasma prolactin concentrations. The prolactin concentration was maintained at a low level under short days in both intact and SCGX goats. The exposure to long days 


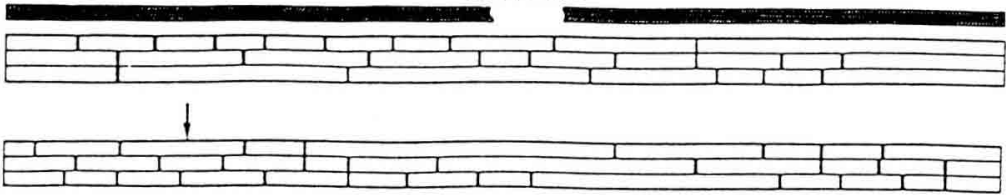

Group 2

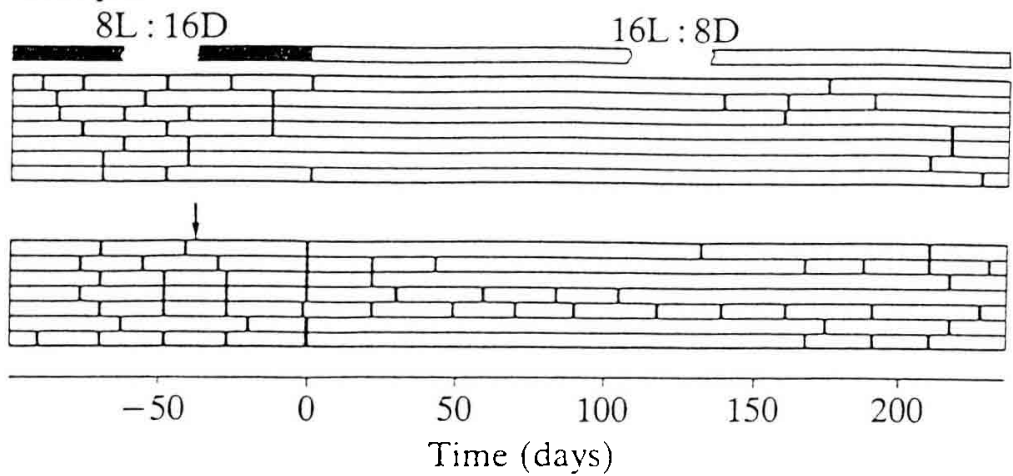

FIG. 2. - Ovulations estimated by fluctuations of plasma progesterone leve/s in female goats in groups 1 and 2. In each group, intact (upper panel) and SCGX (lower panel) goats are shown. Solid vertical bars indicate ovulations, and each horizontal column indicates a sequence of ovulations in an individual goat. Arrows indicate the day on which superior cervical ganglionectomy was performed (Maeda et al., 1986).

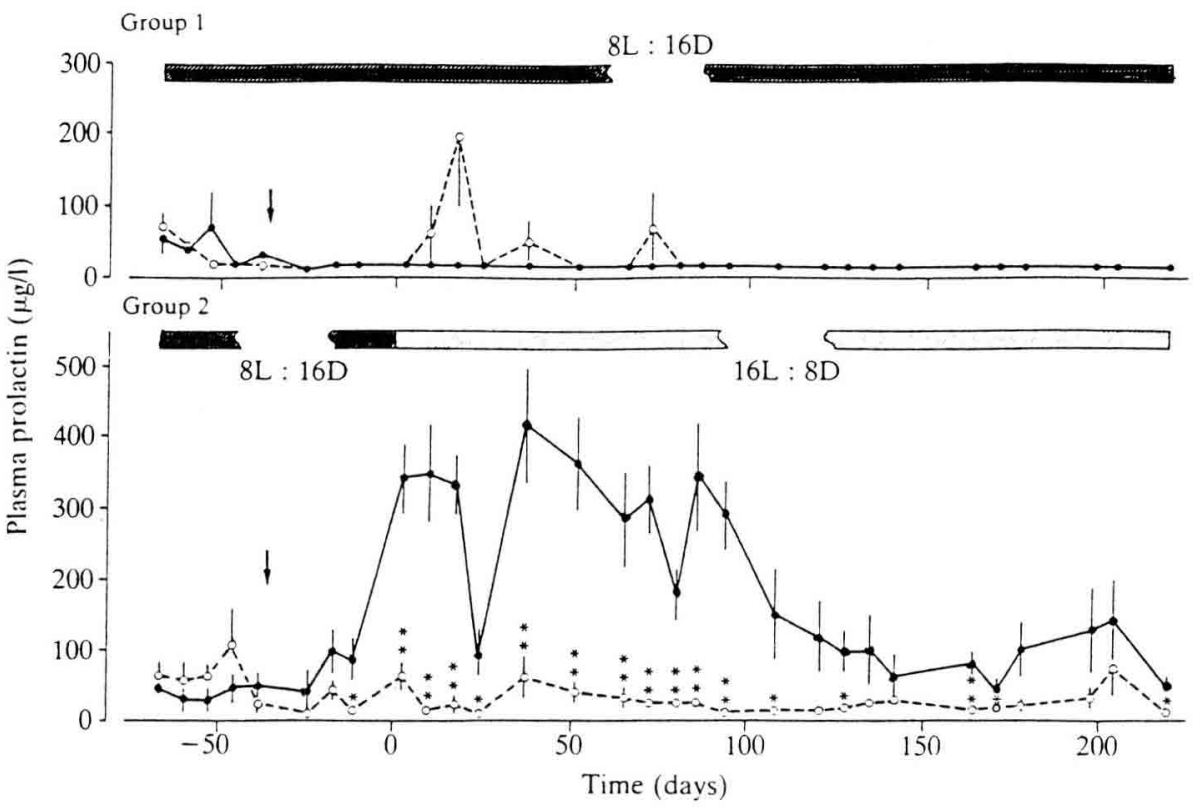

FIG. 3. - Prolactin levels in plasma samples collected weekly from female goats during the dark period (at $22.00 \mathrm{~h}$ ) in groups 1 and 2. Open and closed circles indicate the mean plasma prolactin concentrations of intact and SCGX goats, respectively. Values are mean \pm SEM for three intact and three SCGX goats (group 1) or seven intact and seven SCGX goats (group 2). Arrows indicate the day on which superior cervical ganglionectomy was performed. ${ }^{*} P<0.05$, ${ }^{* *} P<0.01$ compared with intact controls (Mann-Whitney $U$ test). (Maeda et al., 1986). 
immediately increased plasma prolactin concentrations and the prolonged exposure to long days for 150-200 days caused a decrease in plasma prolactin levels, simultaneously with the recurrence of ovulation. In SCGX goats of group 2, these photoperiodic responses of prolactin secretion to long days ceased and plasma prolactin levels were maintained low throughout the experiment.

Figure 4 shows the diurnal change in plasma prolactin concentrations. No diurnal change in plasma prolactin was observed in intact controls of group 1, and the level remaining low throughout the day. SCGX did not affect the 24-h profile of plasma prolactin. The nocturnal peak appeared in intact controls of group 2 immediately after the exposure to long days and lasted throughout the experiment. These nocturnal peaks were not observed in SCGX goats of group 2 ; they either disappeared or were desynchronized with light-dark cycles.

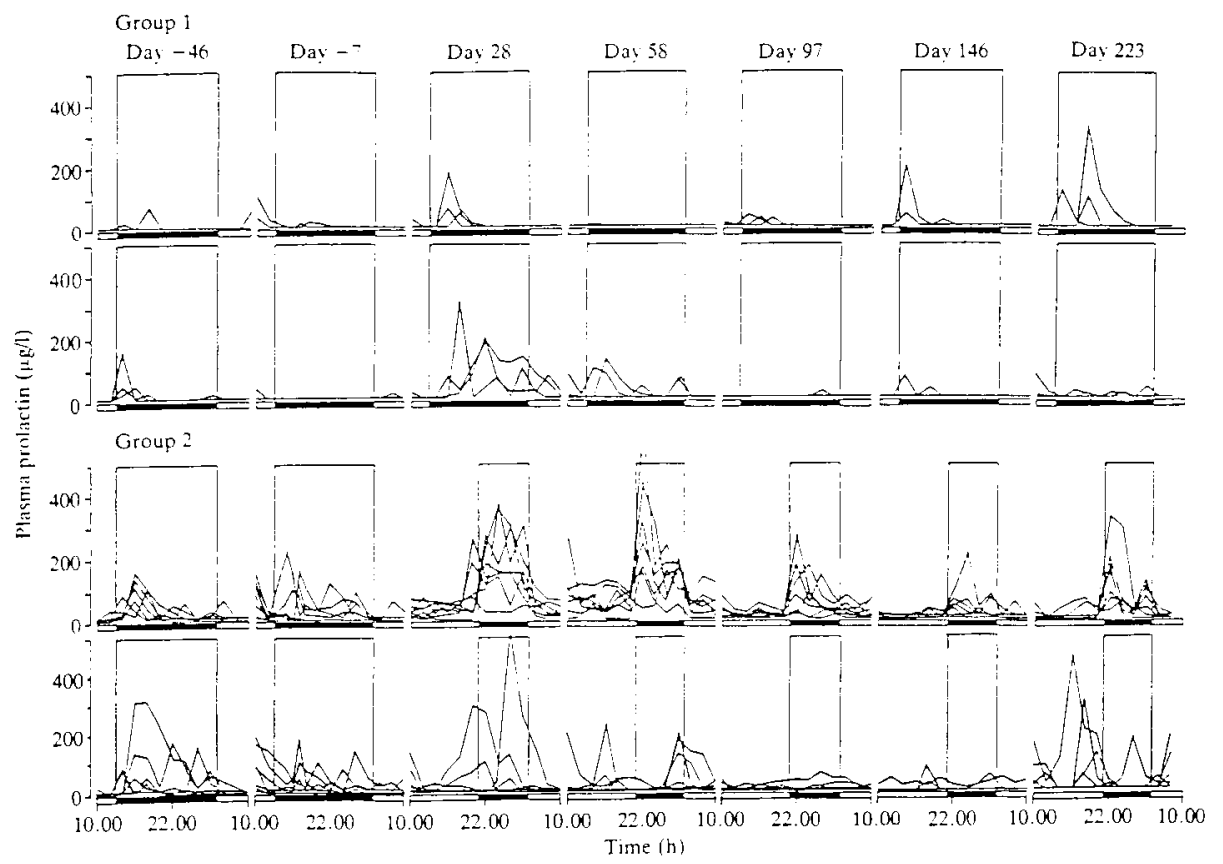

FIG. 4. - Patterns of the diurnal change in plasma prolactin levels in female goats in groups 1 and 2. See fig. 1 for details (Maeda et al., 1986).

The abolishment of the diurnal rhythm of melatonin by SCGX changed the response of gonadal axis and prolactin secretion to long days but not that to short days. This finding suggests that the pattern of melatonin secretion under long days is necessary to induce the photoperiodic responses to long days and that, under natural conditions, the pattern of melatonin secretion should be responsible for regulating the seasonal changes in gonadal function and prolactin secretion by mediating the effect of long days. 
Effects of SCGX on the response of gonadal axis to long days vary from animal to animal (fig. 2), while those of prolactin secretion to long days appeared consistent in each animal (fig. 3). These observations imply that melatonin controls the response of prolactin secretion to long days more directly than that of gonadal axis. The individual variations in the effects of SCGX on the gonadal response to long days imply the participation of some other factors, together with pineal melatonin, in regulating the gonadal response to long days. Bittman et al. (1983) suggested that the annual change in the response to other environmental cues than photoperiod or an endogenous circannual rhythm was expressed in pinealectomized ewes in which the photoperiodic response of gonadal function was abolished. The pineal melatonin secretion may play a partial role in mediating the photoperiodic response of the gonadal axis in ewes and female goats. In contrast to the effect of SCGX on the gonadal response to long days, the nocturnal peak of prolactin which appeared immediately after the exposure to long days vanished after SCGX in all goats of group 2. Buttle (1977) and Brown and Forbes (1980) reported that SCGX or pinealectomy slightly affected the photoperiodic response of prolactin secretion. However, it is likely that they failed to observe the real effect of the abolition of the diurnal change in melatonin on the photoperiodic response of prolactin, because they did their experiments under the condition where only light was controlled but not the temperature. There would be little influence of stress or temperature in our experiment, because the plasma prolactin level was maintained at a low level under short days. The present results clearly show that the pattern of melatonin secretion controls the increase in prolactin observed after the exposure to long days. The photoperiodic response of prolactin secretion is an excellent and simple model to investigate the mechanism by which pineal melatonin controls the photoperiodic response of pituitary hormone secretion.

Since the "continuous" secretion of melatonin was observed almost simultaneously with the recurrence of ovulation and the suppression of prolactin secretion under long days, the "continuous " melatonin secretion seems to be closely related to the photorefractoriness of the gonadal function and prolactin secretion under long days. A similar effect was reported by Almeida and Lincoln (1984), indicating that continued maintenance of rams under long days induced photorefractoriness of gonadal axis, accompanied by an increase in daytime melatonin secretion. Evidence has accumulated that the continuous release of melatonin by melatonin implants suppresses the prolactin secretion in sheep exposed to long days (Kennaway, Gilmore and Seamark, 1982b) and inhibits testicular regression in hamsters exposed to short days (Hoffmann, 1974), and morning injections of melatonin prevents the suppressive action of afternoon injections on the gonadal function in hamsters (Chen, Brainard and Reiter, 1980). These reports imply that a high level of melatonin throughout the light period prevents the transmission of photic information to the mechanism controlling reproductive function and prolactin secretion. Therefore, it is likely that the continuous secretion of melatonin appeared 150 days after the initiation of exposure to long days, negates the effects of long days on gonadal function and prolactin secretion. 


\section{Effects of melatonin replacement by timed melatonin infusion on photoperiodic response of prolactin secretion in SCGX goats.}

We conducted further experiment to determine if the effect of SCGX on photoperiodic response of prolactin is due to the abolition of the diurnal change in melatonin secretion.

Adult female Shiba goats, the Japanese native goat, whose prolactin secretion was reported to show a marked seasonal change (Mori et al., 1985), were ovariectomized and implanted with an oestradiol capsule, since prolactin secretion is thought to be modified by the fluctuating levels of circulating oestradiol (Leong et al., 1983). The goats kept in 10L : 14D for 3 months were transferred to long days $(16 \mathrm{~L}: 8 \mathrm{D})$. Six weeks after the transfer, the pineal was denervated by SCGX and the goats were subjected to the following experiments. Experiment 1: After the control period with saline infusion for a week, SCGX goats were infused with melatonin $(20 \mu \mathrm{g} / \mathrm{h})$ for $8 \mathrm{~h}$ daily $(2100-0500 \mathrm{~h}$; the long-day-type infusion) for 4 weeks via a subcutaneously implanted catheter, and

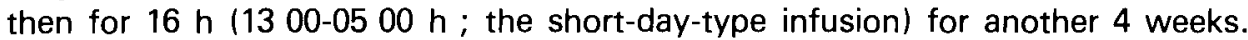
Experiment 2 : The goats were transferred to short days (8L : 16D) 3 months after the end of experiment 1 and melatonin was infused with a similar protocol. Each long-day-and short-day-type melatonin infusion was continued for 10 days. The temperature was maintained at $23^{\circ} \mathrm{C}$ throughout the experiment.

Figure 5 shows plasma melatonin profiles of animals infused with either saline for $8 \mathrm{~h}$, melatonin for $8 \mathrm{~h}$ or melatonin for $16 \mathrm{~h}$ daily. The long-day- and shortday-type infusions into SCGX goats restored the patterns of plasma melatonin that were similar to those in intact goats kept under long days and short days, respectively.

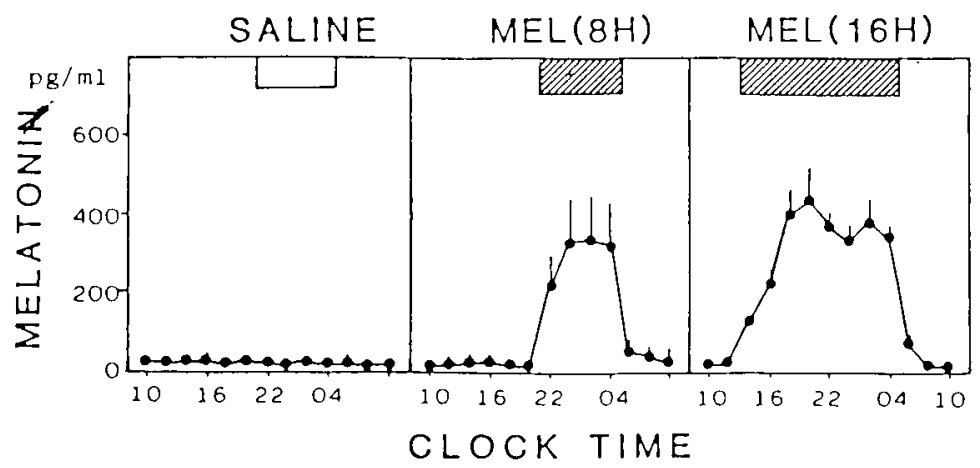

FIG. 5. - Plasma melatonin profiles in SCGX goats when infused with saline for $8 \mathrm{~h}$ or melatonin $(20 \mu \mathrm{g} / \mathrm{h})$ for either $8 \mathrm{~h}$ or $16 \mathrm{~h}$ daily. Open and hatched bars represent the time of infusion of saline and melatonin, respectively. Values are mean \pm SEM $(n=5)$ (from Mori and Okamura, 1986). 
Figure 6 summarizes the effects of melatonin infusion on daily profiles of plasma prolactin in SCGX goats under long (experiment 1) and short (experiment 2) days. The long-day-type melatonin infusion stimulated prolactin secretion, as compared with control saline infusion, inducing a nocturnal rise in plasma prolactin that was comparable to that seen in intact animals exposed to long days. In contrast, the plasma prolactin level was kept at a low level in goats subjected to the short-day-type melatonin infusion. The prevailing photoperiod appeared to have no distinct effect on prolactin responses to melatonin treatments.

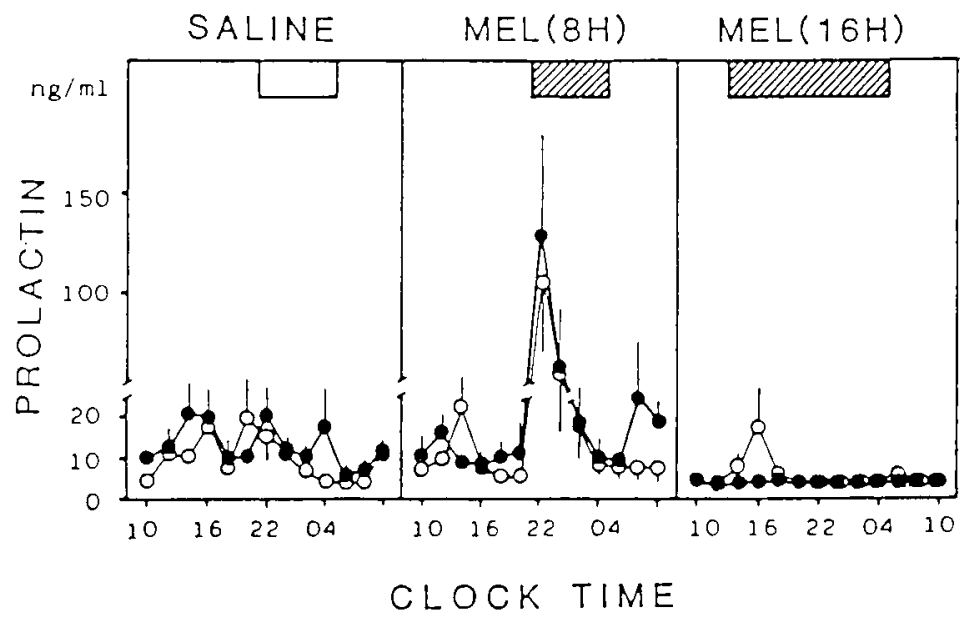

FIG. 6. - Effects of melatonin infusion on prolactin secretion in SCGX goats kept under long days (16L : 8D, closed circle) or short days (8L:16D, open circle). Timings of saline (open bar) or melatonin (hatched bar) infusion are shown at the top. Values are mean $\pm S E M(n=5)$ (from Mori and Okamura, 1986)

The present result demonstrates that the long-day pattern of melatonin induces the nocturnal peak of plasma prolactin, as is observed in intact animals under long days, regardless of the prevailing photoperiod. Therefore, the effect of long days on prolactin secretion is mediated by the secretory profile of melatonin. The prolactin secretion was maintained at a low level in SCGX goats infused with both saline and melatonin for $16 \mathrm{~h}$ (short-day-type infusion). Melatonin administration to sheep under long days, by giving melatonin-adsorbed pelleted feed some hours before the dusk, suppressed prolactin secretion (Kennaway et al., 1982a ; Symons et al., 1983). The implantation of a subcutaneous melatonin capsule that constantly released physiological amounts of melatonin also suppressed prolactin secretion in sheep under long days (Kennaway et al., 1982a ; Lincoln and Ebling, 1985). These facts suggest that prolongation of the melatonin secretion phase probably has an effect equivalent to that of short-day treatment. 


\section{Conclusion.}

The present experiments have provided an evidence that the pineal gland relays the photoperiodic information to prolactin secretion and probably gonadal axis through its secretory profiles of melatonin in the goat.

Colloquium on "Neuroendocrine mechanisms and light control of reproduction in domestic mammals " I.N.R.A., Nouzilly, 17-18 September 1987.

Acknowledgements. - We thank members of the scientific, technical and administrative staff and the students of the Experimental Farm, the University of Tokyo and people in the Laboratory of Veterinary Reproduction, Tokyo University of Agriculture and Technology for their help and continuous encouragement. We are also grateful to Drs. K. Kawashima and T. Johke for the gift of RIA kits of melatonin and prolactin.

Résumé. Implication de la mélatonine dans les changements saisonniers de la fonction gonadique et de la sécrétion de prolactine chez la chèvre.

Chez la chèvre, la cyclicité ovarienne se poursuit en jours courts (8L: 16D) tandis qu'elle s'arrête pendant 150-200 jours en jours longs (16L : 8D). Au cours de la période d'anoestrus en jours longs, la sécrétion de prolactine est augmentée. Des expériences ont été conduites pour rechercher le rôle de la glande pinéale dans le contrôle de la photopériode sur la fonction gonadique et la sécrétion de prolactine chez la chèvre.

En premier lieu, on a examiné les effets de la suppression du changement diurne de sécrétion de la mélatonine sur les réponses à la photopériode de l'axe gonadique et de la sécrétion de prolactine. Des chèvres Saanen, élevées en jours courts $\left(8 \mathrm{~L}: 16 \mathrm{D}, 22+2{ }^{\circ} \mathrm{C}\right.$.) pendant 5 mois, ont subi l'ablation bilatérale du ganglion cervical supérieur (SCGX) pour supprimer l'innervation de leur glande pinéale. Un mois après l'opération, les chèvres opérées et les contrôles ont été séparées en 2 groupes. Les animaux du groupe 1 ont été maintenus en jours courts et ceux du groupe 2 mis en jours longs (16L : 8D). Dans le groupe 1 , les chèvres SCGX et les contrôles ont ovulé régulièrement et le niveau basal de prolactine a été maintenu au cours de la journée.

Chez les contrôles, l'exposition à des jours longs a bloqué l'ovulation et augmenté la sécrétion de prolactine pendant 150-200 jours. Les animaux sont ensuite devenus photoréfractaires : l'ovulation a réapparu et la sécrétion de prolactine a été supprimée. Une sécrétion continue de mélatonine s'est manifestée en même temps que la photoréfraction. La ganglionectomie (SCGX) abolit ou diminue l'inhibition de l'axe gonadique et supprime l'augmentation de la sécrétion de prolactine induite par l'exposition à des jours longs des animaux intacts.

Deuxièmement, on a examiné l'effet du remplacement de la mélatonine par une infusion contrôlée de mélatonine sur la sécrétion de prolactine chez les chèvres SCGX : ceci devait permettre de montrer que l'effet de la ganglionectomie peut être attribué à la suppression du changement diurne de la sécrétion de mélatonine.

Des chèvres Shiba ovariectomisées et $\operatorname{SCGX}(n=5)$ ont été infusées avec de la mélatonine $(20 \mu \mathrm{g} / \mathrm{h}, \mathrm{s} . \mathrm{c}$.) tous les jours pendant $8 \mathrm{~h}$ (infusion de type " jours longs ») ou pendant $16 \mathrm{~h}$ (infusion de type " jours courts $»$ ), pour mimer les profiles nocturnes de mélatonine plasmatique en jours longs et jours courts respectivement. L'infusion de mélatonine de type " jours longs " pendant 9 jours a augmenté la sécrétion de prolactine, induisant une élévation nocturne de prolactine plasmatique comparable à celle observée chez les contrôles intacts en jours longs.

Ces résultats suggèrent que l'information apportée par les cycles " lumière-obscurité " est traduite par la glande pinéale en un signal endocrine, tel que la cinétique journalière de mélatonine, qui contrôle la reproduction chez la chèvre. 


\section{References}

ALMEIDA O. F. X., LINCOLN G. A., 1984. Reproductive photorefractoriness in rams and accompanying changes in the patterns of melatonin and prolactin secretion. Biol. Reprod., 30, 143158.

BITTMAN E. L., DEMPSEY R. L., KARSCH F. J., 1983. Pineal melatonin secretion drives the reproductive response to daylength in the ewe. Endocrinology, 113, 2276-2283.

BROWN W. B., FORBES J. M., 1980. Diurnal variations of plasma prolactin in growing sheep under two lighting regimes and the effect of pinealectomy. J. Endocrinol., 84, 91-99.

BUTTLE H. L., 1977. The effect of anterior cervical ganglionectomy on the seasonal variation in prolactin concentration in goats. Neuroendocrinology, 23, 121-128.

CHEN H. J., BRAINARD G. C., REITER R. J., 1980. Melatonin given in the morning prevents the suppressive action on the reproductive system of melatonin given in late afternoon. Neuroendocrinology, 31, 129-132.

HERBERT J., 1981. The pineal gland and photoperiodic control of the ferret's reproductive cycle, 261-276. In Biological clocks in seasonal reproductive cycles. Eds B. K. FOLLETT \& D. E. FOLLETT. John Wright \& Sons Ltd., Bristol.

HOFFMANN K., 1974. Testicular involution in short photoperiods inhibited by melatonin. Naturwissenschaften, 61, 364-365.

KARSCH F. J., BITTMAN E. L., FOSTER D. L., GOODMAN R. L., LEAGAN S. J., ROBINSON J. E., 1984. Neuroendocrine basis of seasonal reproduction. Recent Prog. Horm. Res., 40, 185232.

KENNAWAY D. J., GILMORE T. A., SEAMARK R. F., 1982a. Effects of melatonin feeding on serum prolactin and gonadotropin levels and the onset of seasonal estrous cyclicity in sheep. Endocrinology, 110, 1766-1772.

KENNAWAY D. J., GILMORE T. A., SEAMARK R. F., 1982b. Effects of melatonin implants on the circadian rhythm of plasma melatonin and prolactin in sheep. Endocrinology, 110, 2186-2188.

LEONG D. A., FRAWLY J. D., NEIL J. D., 1983. Neuroendocrine control of prolactin secretion. Annu. Rev. Physiol., 45, 109-127.

LINCOLN G. A., EBLING F. J. P., 1985. Effect of constant release implants of melatonin on seasonal cycles in reproduction, prolactin secretion and moulting in rams. J. Reprod. Fert., 73, 241-253.

LINCOLN G. A., SHORT R. V., 1980. Seasonal breeding: nature's contraceptive. Recent Prog. Horm. Res., 36, 1-52.

MAEDA K., MORI Y., SAWASAKI T., KANO Y., 1984. Diurnal changes in peripheral melatonin concentration in goats and effects of light or dark interruption. Jap. J. vet. Sci., 46, 837-842.

MAEDA K.-I., MORI Y., KANO Y., 1986. Superior cervical ganglionectomy prevents gonadal regression and increased plasma prolactin concentrations induced by long days in goats. $J$. Endocrinol., 110, 137-144.

MORI Y., MAEDA K., SAWASAKI T., KANO Y. 1984. Effects of long days and short days on estrous cyclicity in two breeds of goats with different seasonality. Jap. J. anim. Reprod., 30. 239-245.

MORI Y., MAEDA K., SAWASAKI T., KANO Y., 1985. Photoperiodic control of prolactin secretion in the goat. Jap. J. anim. Reprod., 31, 9-15.

MORI Y., OKAMURA H., 1986. Effects of timed melatonin infusion on prolactin secretion in pineal denervated goat. J. Pineal Res., 3, 77-86.

MORI Y., TANAKA M., MAEDA K., HOSHINO K., KANO Y., 1987. Photoperiodic modification of negative and positive feedback effects of oestradiol on LH secretion on ovariectomized goats. J. Reprod. Fert., 80, 523-529.

REITER R. J., 1978. Interaction of photoperiods, pineal and seasonal reproduction as exemplified by findings in the hamster. Prog. reprod. Biol., 4, 169-190.

ROBERTS A. C., MARTENSZ N. D., HASTINGS M. H., HERBERT J., 1985. Changes in photoperiod alter the daily rhythms of pineal melatonin content and hypothalamic beta- 
endorphin content and luteinizing hormone response to naloxone in the male Syrian hamster. Endocrinology, 117, 141-148.

SYMONS A. M., ARENDT J., LAUD C. A., 1983. Melatonin feeding decreases prolactin levels in the ewe. J. Endocrinol., 99, 41-46.

YOSHIOKA Z., 1961. Studies on the artificial control of the sexual activity in ewes and she-goats. Jap. J. anim. Reprod., 7, 93-102. 